\title{
MOBАЗНА ّ̈СВА
}

\author{
Hermann Bieder
}

Salzburg

\author{
Z historii białoruskiej gramatykografii: \\ Rękopiśmienne gramatyki Karusia Kahańca \\ i Antona Łuckiewicza w aspekcie porównawczym
}

Początki białoruskiej gramatykografii są mało zbadane. Do najwcześniejszych prób kodyfikacji nowego białoruskeigo języka literackiego należą niedokończone i niewydane dotąd gramatyki rękopiśmienne Karusia Kahańca (początek XX wieku) i Antona Łuckiewicza (Wilno 1916). Podstawą do porównania obu gramatyk służą monografia Iwana K. Hermanowicza Беларускія мовазнаўцы. У двух тамах, t. 1, Minsk 2006 (rozdział Карусь Каганеu, s. 178-190) oraz rękopiśmienny tekst gramatyki Antona Łuckiewicza (Anton Luckiewič: Biełaruskaja hramatyka. Čaść I. Fonetyka $i$ etymologija, Wilnia 1916 hod, 72 s.), który został znaleziony na początku lat 1990-ch przez niemieckiego uczonego Karla Gutschmidta na Uniwersytecie Hamburskim. Planowana edycja gramatyki Łuckiewicza jest przeze mnie $\mathrm{w}$ zasadzie zakończona i powinna wkrótce zostać wydana.

Wymienione pierwsze gramatyki nowego białoruskiego języka literackiego (abstrahując od wcześniejszych nieopublikowanych prób kodyfikacji XIX wieku) składają się z rozdziałów fonetyki i morfologii, nie zawierają jednak rozdziału o składni. W swoich gramatykach obaj autorzy omawiali fonetykę tylko pobieżnie, koncentrując się przede wszystkim na morfologii. Gramatyka Kahańca napisana jest cyrylicą, w przeciwieństwie do łacińskiej pisowni gramatyki Łuckiewicza (w cytatach uwzględniam różne alfabety). 


\section{Fonetyka}

W fonetycznej części obaj autorzy niedokładnie rozgraniczają pytania dotyczace pisowni i fonetyki, co jest metodycznie błędne. Skutki tego uwidaczniają się w klasyfikacji inwentarza dźwięków i systemu ortograficznego. Przy klasyfikacji liter względnie dźwięków Kahaniec wychodzi z systemu rosyjskiej cyrylicy, podczas gdy Łuckiewicz nawiązuje do systemu pisma łacińskiego w wersji polskiej. Pod względem graficznym Kahaniec rozdziela litery na znaki samogłoskowe i spółgłoskowe; Łuckiewicz natomiast analizuje z punktu widzenia fonetyki i rozdziela inwentarz fonemów na samogłoski, półsamogłoski $(j, \breve{u})$ i spółgłoski. Na podstawie pisemnej fiksacji dźwięków Kahaniec rozróżnia twarde i miękkie (jotowane) znaki samogłoskowe (na wzór pisowni rosyjskiej); odnośnie wymowy błędnie przeciwstawia Łuckiewicz grupę „twardych" samogłosek $(a, e, o, u, y)$ miękkiej samogłosce $i$ (w oparciu o pisownię polską). Znaki spółgłoskowe pisma łacińskiego dzieli Kahaniec na proste $(l, m, n$ etc.) i złożone $(r z, c z, s z)$. Słusznie rozgranicza Łuckiewicz spółgłoski miękkie i twarde. Z punktu widzenia ortografii i fonetyki rozgranicza Kahaniec litery (o wartości dźwiękowej) od (specyficznych) znaków fonetycznych (o funkcjach suprasegmentalnych) i znaków interpunkcji. W odróżnieniu od Kahańca Łuckiewicz przeciwstawia tylko litery i znaki interpunkcji. Z powyższych danych wynika, że Kahaniec i Łuckiewicz analizują w metodycznie podobny sposób skład liter i dźwięków białoruskiego języka literackiego. Możliwym jest, że Łuckiewicz miał wgląd do rękopisu Kahańca, albowiem wiadomym jest, że Kahaniec i Jakub Kołas (który współpracował z Łuckiewiczem w redakcji gazety Naša Niva) pozostawali w bliskim kontakcie. Możliwym jest również, że podobny opis fonetycznego i ortograficznego systemu białoruskiego języka literackiego w obu gramatykach opiera się po prostu na stanie wiedzy w ówczesnych gramatykach szkolnych języka rosyjskiego i polskiego. Poza tym należy wspomnieć, że Łuckiewicz zajmuje się różnymi poszczególnymi problemami białoruskiej fonetyki i pisowni (na przykład realizacja samogłosek akcentowanych i nieakcentowanych, zmiana miejsca nacisku w paradygmatach słowotwórczych, protezy spółgłoskowe i samogłoskowe, ruchome samogłoski, zapożyczone fonemy i t. d.), których to Kahaniec w ogóle nie porusza.

\section{Morfologia}

Rozdział morfologii jest podzielony w obu gramatykach według tradycyjnych założeń nauki o częściach mowy. Jednakże kolejność części mowy 
w obu gramatykach jest różna. Kahaniec omawia części mowy w następującej kolejności: rzeczownik, przymiotnik, czasownik, liczebnik, zaimek, przyimek, przysłówek, spójnik i wykrzyknik. Łuckiewicz opisuje części mowy w nieco odrębnej kolejności: rzeczownik, przymiotnik, liczebnik, zaimek, czasownik, przysłówek, spójnik, przyimek i wykrzyknik. Kahaniec i Łuckiewicz wywodza potrzebne do opisu systemu językowego terminy gramatyczne z cech semantycznych i właściwości funkcjonalnych każdej części mowy. Analizując poszczególne części mowy obaj autorzy koncentrują się na definicji odpowiedniej części mowy, jej semantycznej klasyfikacji i charakterystyce oraz właściwościach składniowych. W końcu kładą nacisk na opis kategorii gramatycznych i typów fleksyjnych odpowiedniej części mowy.

Rzeczowniki podzielone są w obu gramatykach z punktu widzenia semantyki na imiona pospolite i własne. Kahaniec omawia kategorie rzeczownika $\mathrm{w}$ przeciwieństwie do Łuckiewicza w następującej kolejności: liczba, rodzaj gramatyczny i przypadek; Łuckiewicz - rodzaj gramatyczny, przypadek i liczba. Obaj gramatycy rozróżniają trzy liczby, mianowicie liczbę pojedynczą, mnogą i podwójną. Również co dotyczy rodzaju gramatycznego rzeczownika obaj autorzy zgodnie dzielą na męski, żeński i nijaki. Oprócz tego obaj gramatycy wymieniają grupę rzeczowników, mającą naturalną płeć męską albo żeńską. W kategorii przypadków rozróżnia Kahaniec osiem przypadków, Łuckiewicz - tylko siedem. Różnica ta spowodowana jest przez to, że Kahaniec rozdziela specyficznie wołacz na dwie funkcje - przypadek zwracania się i przypadek odpowiedzi (прыпадак клічы, прыпадак водзыву Г 186). Kolejność wyliczenia poszczególnych przypadków jest jednakowa w obu gramatykach (wołacz figuruje po mianowniku).

Punktem wyjścia do ustalenia czterech deklinacji w odmianie rzeczowników dla obu autorów jest rodzaj gramatyczny i system fleksyjny. Rozróżniają oni w konwergentnej kolejności: rzeczowniki rodzaju męskiego na spółgłoskę twardą i miękką oraz $j$, a także rodzaju nijakiego na -o i -e [deklinacja o temacie -o]; rodzaju żeńskiego i męskiego na - $a,-j a$ [deklinacja o temacie - a]; rodzaju żeńskiego na spółgłoskę miękką albo twardą [deklinacja o temacie -i]; rodzaju nijakiego na -jo i -ja [resztki deklinacji spółgłoskowych]. Obaj filolodzy podają także paradygmaty czterech typów deklinacyjnych i komentują ich osobliwości fleksyjne. Warto zwrócić uwagę na to, że obaj podają formy wołacza w paradygmatach rzeczowników żywotnych i nieżywotnych wszystkich czterech deklinacji (oraz ich podtypów) w liczbie pojedynczej i mnogiej, i to wbrew temu, że w mowie mówionej odróżniają się one jednak tylko w niektórych wypadkach (w liczbie pojedynczej rzeczowników żywotnych i nieżywotnych pierwszej i drugiej deklinacji) od 
form mianownika/biernika. Oprócz tego Kahaniec i Łuckiewicz starali się o kodyfikację form narzędnika liczby podwójnej zachowanych również tylko w wypadku niektórych rzeczowników.

Przedstawienie przymiotnika przez Kahańca i Łuckiewicza zasadniczo się nie różni. Z semantycznego punktu widzenia obaj filolodzy dzielą przymiotniki na odnośne i jakościowe (Łuckiewicz wspomina poza tym typ przymiotników dzierżawczych). W przeciwieństwie do Łuckiewicza Kahaniec podaje również formy zdrobniałe przymiotników jakościowych. Łuckiewicz wskazuje wyraźnie na kategorie przymiotnika (rodzaj gramatyczny, liczba i przypadek), podczas gdy Kahaniec wspomina je tylko w ramach paradygmatów. Łuckiewicz dzieli odmianę przymiotników w liczbie pojedynczej i mnogiej na typy deklinacyjne twarde, miękkie i mieszane, podczas gdy Kahaniec ogranicza się przypuszczalnie tylko do podania wzorów deklinacyjnych wszystkich rodzajów w liczbie pojedynczej i mnogiej. W paradygmatach przymiotników jakościowych obaj autorzy odróżniają końcówki pełne (przydawkowe) i skrócone (orzecznikowe). Łuckiewicz rozróżnia poza tym nieakcentowane i akcentowane końcówki przymiotnikowe. Obaj włączają wołacz do systemu deklinacyjnego przymiotnika, jednakże postulowane formy wołacza w liczbie pojedynczej i mnogiej nie odróżniają się od form mianownika. W miejscowniku liczby pojedynczej rodzaju męskiego i nijakiego Kahaniec wprowadza przypuszczalnie (z tekstu nie wynika to wyraźnie) końcówkę przymiotnikową -om/-iom, podczas gdy Łuckiewicz nie włącza tę (rosyjską) końcówkę do paradygmatu przymiotnikowego. Zgodnie z oczekiwaniem obaj filolodzy dzielą stopniowanie na formy równe, wyższe i najwyższe. Dodatkowo Łuckiewicz omawia deklinację stopnia wyższego (włącznie z alternacjami morfonologicznymi) oraz supletywne formy stopniowania.

Obaj filolodzy opisują czasownik w odniesieniu do kategorii gramatycznych i systemu fleksyjnego. Kahaniec omawia kategorie czasownikowe w następującej kolejności: czas, tryb, osoba, strona i aspekt, a opuszcza przypuszczalnie liczbę. Łuckiewicz omawia kategorie czasownikowe w odmiennej do Kahańca kolejności, a mianowicie: strona, aspekt, tryb, czas, liczba i osoba. Odnośnie kategorii czasu Kahaniec rozróżnia trzy czasy czas teraźniejszy, przeszły i przyszły. Formy przyszłe dzieli na trzy rodzaje: a) syntetyczne formy czasowników aspektu dokonanego (typ зраблю) i analityczne formy czasowników niedokonanych z czasownikiem posiłkowym быць (typ буду рабіиь); b) syntetyczne formy czasowników aspektu dokonanego i niedonanego stworzone przy pomocy czasownika posiłkowego імаці (typ зрабічіму і рабіuіму); c) analityczne formy czasowników aspektu niedokonanego stworzone przy pomocy słowa posiłkowego меці (typ маю рабічь). 
Łuckiewicz zaplanował jeszcze bardziej złożony system czasów, wprowadzając podział nie tylko w czasie przyszłym, lecz również w czasie przeszłym. Dla niego system czasów składa się z czasu teraźniejszego, dwóch czasów przeszłych (przeszły i zaprzeszły) i kilku typów czasu przyszłego: a) analityczny niedokonany czas przyszły z prepozycyjnym czasownikiem posiłkowym budu albo maju, albo także z postpozycyjnym słowem posiłkowym maju w połączeniu z bezokolicznikiem niedokonanym (typu budu rabić, maju rabić, rabicimu), b) czas przyszły dokonany składający się z dokonanej formy czasu teraźniejszego albo postpozycyjnego słowa posiłkowego maju/imu w połączeniu z bezokolicznikiem dokonanym (typu zrablju albo zrabicimu). A zatem obaj gramatycy mieli różnorodne idee w odniesieniu do realizacji form czasowych czasu przeszłego, jednakże nie do czasu teraźniejszego i przyszłego. W obu gramatykach zgodny jest podział kategorii trybu (tryb orzekający, rozkazujący, przypuszczający, bezokolicznik) oraz osoby gramatycznej (pierwsza, druga, trzecia osoba). W odniesieniu do kategorii strony znowu pojawiają się różnice w obu gramatykach, przy czym mieszają obaj tranzytywność/intranzytywność z kategorią trybu. Kahaniec dzieli wspomnianą kategorię na stronę czynną, zwrotną, wzajemną (reciprocum) i nieprzechodnią. Łuckiewicz rozróżnia wstępnie tranzytywność od nietranzytywności oraz dzieli tranzytywność na stronę czynną, bierną, zwrotną i wzajemną. Aspekt czasownikowy dzielą zgodnie Kahaniec i Łuckiewicz na niedokonany (czynności trwałe lub wielokrotne) i dokonany (czynności rezultatywne lub jednokrotne). Także odnośnie podziału liczby na pojedynczą i mnogą wywody Kahańca i Łuckiewicza pokrywają się.

Kahaniec i Łuckiewicz różnorodnie interpretują system koniugacyjny. Kahaniec odróżnia tylko dwie koniugacje, przy czym zalicza do pierwszej czasowniki z segmentami wygłosowymi -аць/-яць albo -aцi/-яui oraz - ubl i -ui, do drugiej zaś czasowniki z segmentami wygłosu -bıui/-iui. W przeciwieństwie do niego Łuckiewicz rozróżnia trzy koniugacje: Do pierwszej zalicza czasowniki z koncówką 1 . osoby liczby pojedynczej czasu teraźniejszego na -m (typu jem, dam), do drugiej należą czasowniki z samogłoską tematyczną - - - w 2.-3. osobie liczby pojedynczej i 1.-2. osobie liczby mnogiej czasu teraźniejszego (typu hulaješ), trzecia koniugacja dotyczy czasowników z samogłoską tematyczną $-i /-y$ we wspomnianych powyżej osobach czasu teraźniejszego (typu lubiš/haryš). Kahaniec i Łuckiewicz już rozróżniają w werbalnej fleksji proste (syntetyczne) i złożone (analityczne) formy czasownikowe. Obaj autorzy uwidaczniają koniugacje przy pomocy paradygmatów form czasownikowych. Łuckiewicz dostarcza poza tym szczegółowy komentarz do podtypów koniugacji zawierających specyficzne końcówki oso- 
bowe, alternacje morfonologiczne oraz właściwości akcentu słownego i t. d.). Dodatkowo kładzie on nacisk na wytłumaczenie wywodu form czasownikowych z tematu czasu teraźniejszego i bezokolicznika. W końcu szczegółowo omawia tworzenie imiesłowów oraz imiesłowów przysłówkowych.

Liczebniki Kahaniec i Łuckiewicz dzielą w jednakowej kolejności z punktu widzenia semantyki na główne, porządkowe, ułamkowe i zbiorowe, z tą różnicą że Łuckiewicz dodaje do nich jeszcze liczebniki mnożne. Dodatkowo dzieli Łuckiewicz liczebniki jeszcze na określone i nieokreślone. Zarówno Kahaniec jak i Łuckiewicz zaliczają niektóre rzeczowniki o znaczeniu ilościowym, jak naprzykład paławina, ćwierć, para, dziesiatak, sotnia, do liczebników. Zgodnie z tym, obaj gramatycy twierdzą, że liczebniki mogą być odmieniane jak rzeczowniki lub przymiotniki. Zasługuje na uwagę, że paradygmat liczebnika sto zawiera niemalże zgodne archaiczne formy przypadkowe w obu gramatykach.

Również przysłówek dzielą obaj autorzy podobnym sposobem według jego znaczenia i wywodu na kilka semantycznych grup: Kahaniec wylicza sześć znaczeniowych grup przysłówków, a mianowicie: miejscowe, czasowe, przyczynowe, liczebne oraz przysłówki sposobu, do których dodaje również grupe pochodnych (odprzymiotnikowych) przysłówków. Z punktu widzenia semantyki Łuckiewicz dzieli przysłówki na miejscowe, czasowe, przyczynowe i sposobowe; dodatkowo wskazuje na pochodność przysłówków odprzymiotnikowych. Jak widać Kahaniec odróżnia się od Łuckiewicza odnośnie dzielenia przysłówków tylko tym, że uwzględnia jeszcze grupę przysłówków liczebnych.

Opis przyimków w obu gramatykach znacznie się różni, aczkolwiek Łuckiewicz omawia je bardziej szczegółowo. W obu gramatykach zgadza się tylko morfologiczny podział przyimków na proste i złożone. Łuckiewicz omawia dokładnie rozgraniczenie formalnie identycznych przyimków i przedrostków, dzieli przyimki na ilość wymaganych przypadków (jeden, dwa, trzy) i podaje przegląd poszczególnych przypadków (dopełniacz, celownik, biernik, narzędnik, miejscownik), z którymi łączą się różne przyimki. Pozostałe części mowy, mianowicie zaimki, spójniki oraz wykrzykniki, omawia tylko Łuckiewicz, podczas gdy brakuje ich całkowicie u Kahańca.

\section{Terminologia}

Obaj autorzy stworzyli podstawy do rozbudowy terminologii językoznawczej języka białoruskiego, które do tej pory niesłusznie przypisywano tylko B. Taraszkiewiczowi (widocznie z powodu nieznajomości innych daw- 
niejszych źródeł filologicznych). Statystyka wykazała, że Kahaniec stworzył 55 jednowyrazowych oraz 70 dwuwyrazowych terminów językoznawczych. Jednowyrazowe terminy oznaczają z reguły centralne pojęcia morfologii, fonetyki, jak również grafiki, pisowni i interpunkcji. Przeważnie chodzi o następujące terminy jednowyrazowe (rzeczowniki, czasowniki, przymiotniki/imiesłowy): абэцадла, акаюшчьл, аснова (слова), бэзударньл „,nieakcentowany”, галоснік „wykrzyknik [część mowy]”, галасок „dźwięk językowy”, (славянская) гутарка „język słowiański”, двухкроп'е „dwukropek”, заімак, zakavyka „przecinek”, залог „tryb”, злуч „łącznik”, злучок „spójnik”, знак „znak językowy”, звязка „Związek składniowy”, зыıк „dźwięk językowy”, іменнік „rzeczownik”, канчар „końcówka”, клічнік „wykrzyknik”, лічба, лічэбнік, літэра, недаказ „wielokropek”, (полешук) окае, паясняч „przysłówek”, паведанне „syntagma; zdanie”, прачяжка „myślnik”, правопісмо „оrtografia”, прэдслоў „przyimek”, прылметнік, прыппдак, прыссвіст „asybilacja”, пыттаннік „,nnak zapytania”, сагалосньл „spółgłoska”, самагалоснь „samogłoska”, склад „zgłoska”, скланенне „deklinасја”, спражэнне „koniugacja”, ступні прыроўнання „stopnie porównania”, укланенне „tryb”, чужэслоў „cudzysłów”, чын „,aspekt czasownikowy”, чынннік „czasownik”. Pewna ilość tych podstawowych terminów jednowyrazowych tworzących często hyperonymy (terminy nadrzędne) wymagała rozdzielenia terminologicznego (sprecyzowania), to znaczy stworzenie hyponymów (terminów podrzędnych), co osiągnął Kahaniec przez połączenie terminów rzeczownikowych z przymiotnikami przydawkowymi oraz imiesłowami (na przykład паясняч „przysłówek”: мясцовы, часовы, прычиынны, прылетны „przysłówek odprzymiotnikowy”, чвислёньь „przysłówek liczebny”, спосабавьь „przysłówek sposobu”).

W znacznie rozszerzonej gramatyce Łuckiewicza można stwierdzić około dwa razy więcej terminów lingwistyczno-filologicznych aniżeli w pracy Kahańca. Zawiera ona 80 najczęściej jednowyrazowych terminów nadrzędnych oraz 182 dwu- lub wielowyrazowych terminów podrzędnych. Spośród tych 80 jednowyrazowych terminów reprezentujących przeważnie podstawowe pojęcia językoznawcze bazuje 68 na materiale słowiańskim, głównie białoruskim, i tylko 12 na słownictwie greko-łacińskim. Porównanie jednowyrazowych hyperonymicznych terminów gramatyki Łuckiewicza i Kahańca prowadzi do zdumiewającego wniosku, że więcej niż połowa tych terminów pokrywa się albo całkowicie albo przynajmniej częściowo. 29 takich terminów, a mianowicie 27 białoruskich oraz 2 greko-łacińskie, odznaczają się całkowitą (formalną i semantyczną) konwergencją w obu gramatykach: asnowa stowa L $52=$ аснова слова $\Gamma$ 186; asoba $\mathrm{L} 49=$ асоба $\Gamma$ 187; с̌as L 45, 48-49 = час Г 187; častka „element, część; partykuła” L 33, $64=$ uacm- 
кa „część słowa; zgłoska” $\Gamma$ 184; čužesłoŭ L $8=$ чужеслоў $\Gamma$ 183; čyn

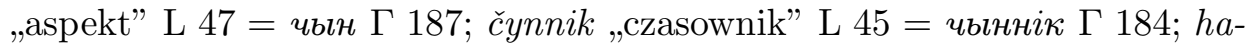
łosnik/hałośnik „wykrzyknik" [część mowy] L 10, 69 = галоснік Г 184, 189; hawaryc' L $3=$ гаварыць $\Gamma$ 181, 182; imiennik „,rzeczownik” L 6-10 = іменнік $\Gamma$ 184; kančar L $6=$ канчар $\Gamma 185,186$; kličnik L $8=$ клічнік $\Gamma 183$; kropka L $8=$ кропка $\Gamma$ 183; ličebnik L 9, $34=$ лічэбнік $\Gamma 184 ;$ mowa L 1-9 = мова $\Gamma 180$; prawopismo LBT 24 [1916]) = правопісмо $\Gamma 182$; prymietnik L 2-32 = прыметнік $\Gamma$ 184; prypadak L $11=$ прыпадак $\Gamma 185$; rod L $11=\operatorname{poд~} \Gamma 185 ;$ siaredzina słowa ,śródgłos, pozycja śródgłosowa" L 5 = сярэдзіна слова $\Gamma 181$; stowa L 2-7 = слова $\Gamma$ 181, 183; wyhawarywас́ „wymawiać” L 3-4 = выгаварыьваџь $Г$ 184; wyražeńnie „wyraz” L 9 $=$ выражэнне $\Gamma$ 184; zaimak L 9, 40 = заімак $\Gamma$ 184; zakawyka „przecinek" L 8 = закавыка $\Gamma$ 183; znak L $4=$ знак $\Gamma$ 180, 181; zyk L 1, 3, 30 $=$ зык $\Gamma$ 181, 183 albo гaлacok „dźwięk” G 184. Spośród wyrazów obcojęzycznych w obu gramatykach używane są tylko terminy hramatyka L Titelblatt $=$ граматыка $\Gamma$ Titelblatt; litera L 4-5 = літэра $\Gamma 183$.

Spośród podstawowych terminów Łuckiewicza i Kahańca dywergencja częściowa figuruje na różnych poziomach językowych: a) dywergencja fonetyczno-ortograficzna: prociažka „myślnik” L 8 // прачяжка Г 183; stupieni pryraŭnańnia L 31 // ступні прыроўнання Г 186; suhałosny (zyk) L 1 albo suhałosnaja (litera) L 4 // сагалоснь Г 184; b) dywergencja morfologiczna: akanne L 3 // акаюшиь Г 182; udareńnie „akcent” L 2 // бэзударны „nieakcentowany” G 182; dwukropie „dwukropek” L 8 // двухкроп'е Г 183; nazwańnie „nazwa” L 10, 12 // назыьаюшчь $\Gamma$ 184; niedaskaz „wielokropek" L 8 // недаказ Г 183; c) dywergencja słowotwórcza: piśmienstwa „piśmiennictwo” L 52 // пісьменнасџь Г 180; prawopisańnie „pisownia, ortografia” L 7 // nравопісмо Г 182; pytnik ,znak zapytania” L 8 // nblтаннік Г 183; złučok „łącznik” L 8 // злуи Г 183; złuč „spójnik” L 10 // злучок $\Gamma$ 184, 189; zwiazywacca „związać się syntaktycznie” L 9 // звяз$\kappa a$ „Związek syntaktyczny" $\Gamma$ 184; d) dywergencja semantyczna: hutarka I „rozmowa” L 3; hutarka II „dialekt” LBT 23 // славянская гутарка „,język słowianski” Г 181; pawiedańnie „syntagma” L 9 // паведанне „syntagma; zdanie" $\Gamma$ 184; [pojęcie „zdanie” wyraża Łuckiewicz poprzez termin cкa3]; skład „,zgłoska; budowa, struktura, skład” L 2-9 // ckлад „zgłoska” Г 183; znak biazzyčny „znak przestankowy” L 8 // бяззычны знак „znak fonetyczny" $\Gamma$ 184; e) dywergencja leksykalna przydawki: znak biazzyčny „Satzzeichen" L 8 // знак застановачны Г 183, 184.

Całkowita dywergencja na planie wyrażenia pomiędzy obiema gramatykami wykazała się tylko w wypadku 11 terminów: admiena čynnikou „odmiana czasowników, koniugacja” L 47 // спражэнне Г 180 albo зме- 
на чыннікаў $Г$ 187; admiena imiennikoŭ, prymietnikoŭ, ličebnikoŭ „odmiana rzeczowników, przymiotników, liczebników" L 9-50 // скланенне іменнікаў i t. d. Г 180, 185 albo змена іменнікаў i t. d. Г 185; с̌ysto „liczba (gramatyczna)" L 11-12 // лiчбa Г 185; hałosny (zyk) albo hałosnaja (litera) „samogłoska” L 1 // самагалоснь Г 184; lad „tryb” L 47 // укланенне Г 187; hałosnaja [litera] L 6 „znak samogłoskowy” // самагалоснь знак Г 184; suhałosnaja litera „znak spółgłoskowy” L 1, 8 // сагалоснь знак Г 184; prystowak „przyimek” L 10, 67 // прэдслоў Г 184, 188, 189; skaz „zdanie” L 9 // паведанне Г 184; skaźnik „przysłówek” L 10, 66 // паясняч Г 184, 188; stan „strona” L 8 // залог Г 187.

Rozmaita objętość tekstu obu gramatyk doprowadziła do tego, że nie wszystkie u Łuckiewicza występujące terminy mają odpowiedniki w pracy Kahańca. Do tych brakujących ekwiwalentów zalicza się m.in. następujące terminy: adznaka „cecha” L 3, 5, 9; čaści mowy L 9; čynnaść L 45; hołas L 1; kaniec słowa L 6; kropka z zakawykaj „średnik” L 8; pačatak słowa L 4; paradak słoŭ „szyk wyrazów” L 9; paŭhałosny „,samogłoska zredukowana typu $j$, ŭ L 1; pieramiena (stowa) „zmiana językowa” L 63; prymieta „cecha” L 26; pytańnie L 11; reč „rzecz, przedmiot” L 10; skaročeńnie „skrót, skrócenie” L 28; sktadnia L 23; udwajeńnie „podwójenie” L 23; ustaŭka „przyrostek" L 14, 59; wymowa L 8; wywod „wywód słowa; derywacja” L 51; zamiena L 2, 3; zmiakčeńnie L 13; značeńnie L 9.

Łuckiewicz używał w swojej gramatyce więcej greko-łacińskich terminów aniżeli Kahaniec. Zapożyczone przez Łuckiewicza z języków klasycznych (z reguly poprzez język polski lub rosyjski) terminy akcent, assymilacija, etymologija, fonetyka, forma, kakofonia, syntaksis, activum, passivum oraz locativus nie spotyka się w rozprawie Kahańca. Również w zakresie dwu- lub wielowyrazowych terminów napotyka się często na zdumiewającą konwergencję w obu gramatykach. Niektóre jedno- i wielowyrazowe terminy spotyka się jednak tylko w gramatyce Kahańca, przy czym chodzi tu o terminy z zakresów grafiki, pisowni, fonetyki oraz morfologii: a) grafika, ortografia: абэиадла ,alfabet, abecadło" Г 180, 181; простьяя сагалосныля „spółgłoski napisane tylko przez jedną literę" $Г$ 184; складаныля сагалосныля „spółgłoski wyrażane przez kilka liter" $Г$ 184; знак зычны „znak dźwiękowy" $\Gamma$ 180; b) fonetyka: галасок „dźwięk” $\Gamma ~ 184$; знак кароткасиі $\Gamma$ 184; знак мяккасиі $\Gamma$ 184; знак гастраты "znak asybilacji” [d'> dz', t'> c'] Г 184; полешук окае Г 182; беларусьи гаворачь д з прысвістам [дз] Г 181; с) morfologia: увелічытныя іменнікі „rzeczowniki zgrubiałe" Г 184; умяншытныля іменнікі „rzeczowniki zdrobniałe" Г 184; збіратныл іменнікі „nazwy zbiorowe” $Г 185$ (por. jednak zbornyje ličebniki L 34); паяснячь ивислёньля „przysłówki liczebne” Г 188; залежныля 
прыметнікі Г 186; незалежныя прыметнікі Г 186; прыпадак водзыву „wołacz” $\Gamma 186$.

\section{Uwagi}

Przykłady z obu gramatyk cytuję według stron, a nie według rozdziałów lub paragrafów. Cytaty z gramatyki Łuckiewicza podaję w oryginale pisma łacińskiego; cytaty z gramatyki Kahańca podane są cyrylicą.

\section{Skróty źródeł}

L - Anton Łuckiewič: Biełaruskaja hramatyka. Čaść I. Fonetyka i etymologija. Wilnia. 1916 hod. 72 S. [rękopis hektograficznie powielony].

Г - Германовіч I. К.: Беларускія мовазнаўцы. У двух тамах. Складанне, прадмова М. Р. Прыгодзіча, І. С. Ройды. Т. 1. Мінск 2006.

ЛВТ - Луцкевіч А.: Выбраныя творы. Праблемы культуры, літаратуры і мастацтва. Укладаньне, прадмова, камэнтары, індэкс імёнаў, пераклады з польскае і нямецкае А. Сідарэвіча. Мінск 2006.

\section{Literatura}

Германовіч-Абабурка 1994 - Беларуская мова. Энцыклапедыя. Пад рэд. А. Я. Міхневіча. Мінск 1994.

$$
\text { РЭ }
$$

У артыкуле разглядаюцца ў параўнаўчым аспекце дзве граматыкі: адна Каруся Каганца і другая Антона Луцкевіча. Выяўляюцца ды падкрэсліваюцца сыходжанні іх граматык па структуры, зместу, спосабах падачы матэрыялу, дэфініцыях, а таксама тэрміналогіi. Сыходзіцца ў іх і класіфікацыя ўсяго інвентара гукай, а на ўзройні марфалогіi - граматычных катэгорый, субкатэгорый ды семантычных груп акрэсленых частак мовы. Каганец абапіраўся, відаць, на рускую граматычную традыцыю, а Луцкевіч наадварот - на польскую граматыкаграфію (што выяўляецца асабліва ў вырашэннях пытанняў графікі, правапісання і фанетыкі). Граматыка Луцкевіча бачыцца больш вартаснай, чым праца Каганца. Значная частка граматыкі Луцкевіча, напісаная ім, як мяркуецца, некалькі гадоў пасля выхаду граматыкі Каганца, з'явілася у выніку самастойнай і арыгінальнай працы гэтага аўтара.

Ключавыя словы: беларуская мова, кадыфікацыя літаратурнай мовы, напісанне граматыкі, фанетыка, марфалогія, мовазнаўчая тэрміналогія, Карусь Каганец, Антон Луцкевіч. 


\section{S T R E S Z C Z E N I E}

Wspólne cechy obu gramatyk odnośnie struktury, treści, sposobu przedstawiania, definicji, jak również terminologii są nie do przeoczenia. W zakresie fonetyki dotyczy to klasyfikacji inwentarza dźwięków, w obrębie morfologii gramatycznych kategorii oraz subkategorii jak również semantycznych grup określonych części mowy. Kahaniec opierał się raczej na rosyjskiej gramatycznej tradycji, Łuckiewicz przeciwnie na gramatykografii polskiej (co uwidacznia się szczególnie w pytaniach dotyczących grafiki, pisowni oraz fonetyki). Obydwaj wymienieni autorzy nie mieli wykształcenia filologicznego, co pod pewnymi względami odbiło się niekorzystnie na interpretacji niektórych faktów językowych. Pod względem objętości oraz poziomu naukowego gramatyka Łuckiewicza przewyższa pracę Kahańca. Ponieważ gramatyka Łuckiewicza sporządzona została przypuszczalnie kilka lat po pracy Kahańca, wnioskuje się z tego, że Łuckiewicz był zaznajomiony z pracą Kahańca i wzorował się na niej w pewnych wypadkach. Szczególnie przemawia za tym fakt, że liczne terminy gramatyczne pokrywają się w obu pracach. Znaczna część gramatyki Łuckiewicza powstała jednak jako wynik samodzielnej, oryginalnej pracy autora.

\section{S U M M A R Y}

\section{THE HISTORY OF BELARUSIAN GRAMMATICOGRAPHY: KARUS KAHANETS' AND ANTON LUTZKIEVICH'S HANDWIRITTEN GRAMMARS FROM A COMPARATIVE PERSPECTIVE}

The article discusses early attempts of codification of modern Belarusian literary language made by an artist Karus Kahanets and a politician Anton Lutzkevich, the authors of handwritten unpublished school grammars, at the beginning of the 20th century. A comparative analysis revealed close connection between the two grammars in the field of phonetics, morphology and linguistic terminology.

Key words: Belarusian language, codification of literary language, grammar writing, phonetics, morphology, linguistic terminology, Karus Kahanets, Anton Lutzkevich. 